\title{
Theory and Practice of Citizenship Education
}

\author{
Wiel Veugelers and Isolde de Groot
}

\section{Introduction}

Education has an important task in preparing young people for their participation in society. Citizenship is now the central concept for scholars and practitioners who engage in this educational task. It concerns both legal rights and obligations, and how people live together in communities, nations, and in the global world. People can, and often do, have different ideas about what makes a good citizen and what are good ways of living together. They may also have different ideas about how education can contribute to citizenship development.

This EDIC+ module of the University of Humanistic Studies focuses on different ideas about citizenship and citizenship education in theory, policy and practice. In the first part of the module, students use a comparative approach to examine commonalities and differences between nations in Europe and in the non-Western world. In the second half, students evaluate educational practices and policies of schools and NGOs in light of key theoretical concepts, and develop an educational activity.

\subsection{Broadening and Deepening the Concepts of Citizenship and Citizenship Education}

The concepts of citizenship and citizenship education are now central concepts in the theory, research, policy and practice of education. Citizenship education refers to how education can support students' development of identity. In the last few decades the concept of citizenship has been both broadened and deepened (Veugelers, 2011a). 'Broadened' means that citizenship is no longer just linked with the national state, but also with regional arrangements (e.g. European citizenship), and even with the whole world through the concept of global citizenship. 'Deepened' means that the concept of citizenship has been extended from the political level to the social and cultural level. It is about living together in a particular society. As a result of this deepening, citizenship has strengthened its connection with moral development. Citizenship is now the central concept in both policy and research when examining the role of education in developing students' identity. 
In many countries the policy of citizenship education has intensified recently: in Europe, in other parts of the Western world, in Asia, but also in Latin America. It is a paradox that in an era dominated by neo-liberal policy with a strong market orientation and limited government interference, education policy now focuses so strongly on citizenship education. The identity development of a person is not left to the autonomy of the free individual, but is made the target of a direct socialisation effort by schools, coordinated by the national government.

From a positive perspective, one may argue that educational policy is a democratically chosen manner of socialising human beings into a democratic way of life and into a lively civic and political engagement. However, even within such a democratic framework, different ideological articulations are possible, and the specific articulation depends on the embedded configuration of moral values like adaptation, individualisation, and social concern.

This EDIC+ module of the University of Humanistic Studies aims to provide students with knowledge of different theoretical approaches to citizenship education, an in-depth understanding of policies at the national and European level, and skills to design and evaluate practices of citizenship education. The module will be theoretical, comparative and practice-oriented.

\section{Transitions in Citizenship Education Research}

As research on citizenship education is becoming a solid academic subdiscipline, it is interesting to examine key transitions in the academic field of citizenship education over the past five decades. Traditionally, the academic field of citizenship and citizenship education was part of the discipline of political science. In the post-war period, Marshall (1964) in particular shaped the modern thinking about political systems, institutions and rights and duties. In the seventies, sociologists like Isin and Turner (2002) and Bourdieu (1984) entered the field, making the connection between the political arena and society stronger. During this period, the focus in the sociology of education was on the reproduction of society, that is, on social and political power relations and positions.

Critical pedagogy emerged as a novel field of research with the work of Freire (1985) and was expanded by Giroux (1989) into a more comprehensive theory of building democracy through education, making citizenship theory and research more dynamic and transformative (Veugelers, 2017a). Apple and Beane (2005) focused on democratic schools and Mc Laren (1989) on life in schools' of underprivileged students. 
Political psychologists like Torney-Purta (2002) initiated attention for the cognitive and affective processes involved in youngsters' social and political development. Philosophers, for example McLaughlin (1992), Nussbaum (1997) and Crick (1999) entered the debate about what citizenship and in particular democracy and participation means, and how education can or cannot contribute to citizenship development. This has been followed more recently by the more political philosophy of Mouffe (2005), which emphasises contradictions (agonism) in citizenship and democracy.

Within education studies, related disciplines started to use the term citizenship as well. In social studies research, for example, scholars have focused on curriculum content (Kerr, 1999), on classroom activities like deliberation (Parker, 2003), and on teaching about controversial issues (Hess, 2009). Scholars on multicultural education have argued that learning about, through and for diversity and plurality is at the very heart of citizenship education (e.g. Banks, 2004, 2017). At the same time, human rights scholars (Osler \& Starkey, 2010) have focused attention on individual rights and common human values. Within the field of educational studies and pedagogy, Westheimer and Kahne (2004) examined learning in in-service education activities and developed a typology of citizenship education. Biesta (2011a, 2011b) explored 'subjectification' in relationship to citizenship education and on how students actively give meaning to life and find their way in the world. School effectiveness research resulted in comparative studies like the International Civic and Citizenship Study (ICCS, 2010, 2017). About 30 countries participated in these comparative studies on practices and effects of citizenship education.

In research on moral education, Haste (2004) and Oser and Veugelers (2008) linked morality with society and the political domain: moral values are not considered as abstract notions but as embedded in societal contexts and political power relations. The moral and political must be linked more closely together: the moral must become more political and the political more moral (Veugelers, 2017a).

Post-colonial studies (Andreotti, 2011; Torres, 2017) went beyond a Western perspective on citizenship and citizenship education and emphasised social justice and societal transformation (Veugelers, 2017b). A specific Asian perspective has been examined by scholars like Kennedy, Lee and Grossman (2010) and Sim (2011). They showed that an 'Asian' perspective has a more positive view on being social and of attachment to local and regional traditions.

More recently, the concept of citizenship has also been used in countries with strong internal conflicts, for instance by Reilly and Niens (2014) in relation to Northern Ireland and Goren and Yemini (2016) with regard to Israel. The concern for sustainability has also become part of citizenship: the citizen 
and his surroundings should become not only democratic but also sustainable (Gaudelli, 2016).

All these extensions of citizenship have made the concept very complex. All these researchers, with their own knowledge base, specific articulations of concepts and research methods, have contributed to what we can now call the academic sub-discipline of citizenship education studies. It is a dynamic field with different social, moral, cultural and political perspectives.

\section{Different Political Orientations of Citizenship}

Traditionally, distinctions in citizenship have been made in terms of for instance weak and strong (Barber, 1984), making citizenship appear as a linear construct. However, citizenship can have different ideological articulations. The academic (Western) scholarship on citizenship is closely related to especially the concept of democracy, but citizenship occurs just as well in nondemocratic societies, in the form of an authoritarian citizenship. Citizenship is a concept that pertains to participation in a nation and society, without defining the type of participation. It is in fact an ideologically neutral concept.

Even regarding democracy, there are many different ideas (see e.g. Gutman, 1987; Touraine, 1997; Mouffe, 2005; Veugelers, 2007; Biesta, 2011a; De Groot, 2013). Scholars have developed different positions on, for example, the way people need to contribute in order for democracy to thrive, the influence that people can have on politics, and the societal and civil domains that can be part of democratic processes like labour organisations, educational institutions, and the role of non-governmental organisations (NGOS). The debates are essentially about the balance of two elements of democracy: freedom and equality (Mouffe, 1998, 2018). Freedom refers to being entitled to have and express one's own opinions and the possibility to participate in democracy. Equality refers to the opportunity to participate in democratic processes and the possibility of equal power relations in democracy. Freedom and equality together form part of a political vision on democracy.

\subsection{Different Educational Goals and Types of Citizenship}

Educational systems, schools within a system and teachers within a school; they can all have different educational goals, also with regard to citizenship and citizenship education. In several research projects (with both quantitative and qualitative instruments), we asked teachers, students and parents which educational goals they find important. Statistical analyses showed three clusters of educational goals: discipline, autonomy, and social involvement 
(Veugelers \& De Kat, 2003; Leenders, Veugelers, \& De Kat, 2008a, 2008b, 2012). (See for more conceptual explorations of these clusters Veugelers, 2007, 2017b.) Each cluster expresses a clear and different political articulation.

- Discipline, for example, has to do with listening and behaving well. These are goals that are emphasised especially in the educational movement that is called 'character education' (Lickona, 1991). It is about promoting good behaviour and following norms. In socialisation research, as in the work by the sociologist Durkheim (1923), disciplining is considered an educational task: education teaches you how you should behave.

- Autonomy refers to personal empowerment and formulating your own opinion. These goals are central to the moral development tradition of Kohlberg (Power, Higgins, \& Kohlberg, 1989) but also in the structural sociology of Giddens (1990), with the emphasis on 'agency'. Autonomy can be defined as the experience of freedom, and giving meaning to your own life. In the Western world and in modernity more generally, people's development of autonomy is considered very important.

- The third cluster, social involvement, shows a broad spectrum of social goals: from an instrumental coexistence, a social-psychological empathy, to a social justice-based solidarity and combating inequality in society. In this social spectrum, different scientific orientations can be found: the justice approach by Rawls and Kohlberg, the concept of care by Noddings (2002), and the concept of empowerment by the Brazilian pedagogue Freire (1985). Social involvement can vary greatly in its political orientation.

Our research, with both quantitative and qualitative instruments, shows that these three clusters of discipline, autonomy and social involvement are important educational goals for teachers, students and parents.

\subsubsection{Types of Citizenship}

Further analysing our data (with person-centred factor analyses), we could construct three types of citizenship, expressing different orientations:

- The first type is adaptive citizenship. This type scores high on discipline and social involvement. Socially involved not in a political sense, but in a moral commitment to each other, especially your own community. For autonomy, the scores are not so high for the adaptive type.

- The second type, individualised citizenship, scores high on autonomy and fairly high on discipline but relatively low on social involvement. This type has a strong focus on personal development and freedom, not on the social.

- The third type, critical-democratic citizenship, scores high on social involvement and on autonomy. On discipline this type scores low. We call this type critical-democratic because of its focus on the social and on society, 
a critical engagement with the common good, and a democracy that leaves room for individual autonomy and personal articulation.

In a survey of Dutch teachers in secondary education, with a representative sample, we could conclude that $53 \%$ of teachers pursue a critical-democratic citizenship, $29 \%$ an adaptive type, and $18 \%$ an individualising type. This variety is not the same for the different levels of education: in pre-university secondary education we see more support for the individualised type and in the prevocational education, for the adaptive type. Support for a critical-democratic type was the same for both levels. A reproduction of social class positions and power relationships supported by differences in schooling becomes visible in these citizenship orientations (Leenders, Veugelers, \& De Kat, 2008a).

\subsubsection{Types of Citizenship and Civic Education Practice}

These three types of citizenship each correspond, in an ideal way, to a specific practical operationalisation of citizenship education with an own methodology and a focus on certain goals:

- Adaptive: strong transmission of values, in particular adaptive values, and attention for standards and norms. Teacher-directed education, and students seated in rows. Values are embedded in the hidden curriculum.

- Individualised: strong focus on developing students' independence, and on critical thinking. Students work a lot individually. Values are a personal choice.

- Critical-democratic: focus on learning to live together and to appreciate diversity, and on active student participation in dialogues. Cooperative and inquiry-oriented learning is practiced often. Attention for social values and critical reflection on values.

Of course, the types of citizenship and the corresponding practical classroom interpretations are ideal-typical constructions. In people's views and in educational practice we find many hybrid forms of citizenship and citizenship education. But these three types of citizenship and citizenship education clearly demonstrate that citizenship is not a matter of bad or good citizenship, and that different orientations in the political nature of citizenship and citizenship education are possible. It also shows that nations, schools and teachers can make choices in their educational goals and in their practice of citizenship education.

\subsection{Differences between Goals, Practices, and Experiences of Citizenship Education}

The curriculum can be approached in different ways (Goodlad, 1979): the ideal curriculum (or, the abstract level), the interpreted curriculum (what teachers 
personally want to do), and the operationalised curriculum (the curriculum as practiced in education). At all curriculum levels different articulations of citizenship and citizenship education can be found.

In the previous section, we reported insights from empirical studies on the goals that Dutch teachers pursue. In the following section we focus on education practice: on Dutch teachers' views on the extent to which they realise these goals. Our studies revealed that teachers often find themselves unable to realise these objectives entirely. This is particularly true of the goals of autonomy and social involvement. It is striking that in the Netherlands, teachers as well as parents indicate that discipline in education still receives relatively a lot of attention and is also fairly well developed in students. They realise that it is much more difficult to develop strong autonomy, where students take real responsibility for their own actions and deliberate on alternatives in a grounded manner. The social orientation, and especially the attitude in it, receives even less attention in educational practice and is also more difficult to achieve (Veugelers, 2011a, 2017a).

Adaptation, Individualisation, and the Social: Cultural and Political Differences

In traditional education, the disciplinary adapting mode of citizenship gets a lot of attention. In modern teaching methods with a focus on self-regulating learning and in child-centred pedagogical perspectives, the individual citizenship is more central. This individual orientation is further strengthened in education, in the 'hidden curriculum', by the competition and selection that is strongly embedded in many educational systems. This performativity becomes even more important in an ideology and policy of accountability. Students have to compete with each other and are made responsible for their own educational success. This individual competitive orientation has grown stronger in the Western world in the past decades, and the Netherlands offers a good example. However, Asian countries like South Korea, Singapore and Taiwan are also strongly competitive-oriented.

The social orientation depends largely on cultural and political traditions. The social, in its positive sense of collaboration and social justice, seems to be less embedded in the practice of Western educational systems. Countries with a social democratic political orientation, such as the Scandinavian countries, have a stronger social orientation (Green \& Janmaat, 2011). This also applies for some Latin American countries, as the result of strong social movements focusing on empowerment (Teodoro \& Guilherme, 2014; Veugelers, De Groot, Llovomate, \& Naidorf, 2017; Veugelers, 2017a). In some East Asian countries, there is a social orientation as part of a more collective culture, often infused by Confucianism (Kennedy, Lee, \& Grossman, 2010; Sim, 2015). 
The concept of global citizenship transcends the nation, but this concept shows differences as well (Oxley \& Morris, 2013). In our own theoretical and empirical research on global citizenship, we distinguish an open, a moral, and a social-political global citizenship (Veugelers, 2011b, in press). A socialpolitical orientation stresses the injustice of inequality and seeks more transformation of power relations: it is more political than appealing in general to moral values like in the moral global citizenship. The open global citizenship is presented as neutral, but in fact it is a neo-liberal market orientation.

International comparative studies like the International Civic and Citizenship Education Study $(2010,2017)$ reveal how adolescents think and act in the area of citizenship. Many youngsters support democracy and individual freedom on an abstract level. However, these studies also show that in many Western countries the social and political involvement and the future envisioned involvement of youngsters is not very strong. For example, in Northwest European countries like the Netherlands, the UK and Belgium, youngsters indicate a lack of interest in being involved in politics and the common good. On the other hand, they do express certain political opinions such as restricting rights and state support for immigrants.

In our own research with the three types of citizenship, we find among youngsters a strong focus on autonomy, and a social involvement which is more psychological and focused on their own communities rather than global and social justice oriented (Leenders, Veugelers, \& De Kat, 2008b, 2012). De Groot (2013) studied adolescents' view on democracy and found that many students are not interested in participating in democratic practices, often because they feel that they cannot have any influence.

\subsubsection{Distinguishing Types of Citizenship and Citizenship Education}

The relevance of the distinction between types of citizenship and citizenship education is that it shows how choices can be made at the different policy levels, that these choices have consequences for practices of citizenship education, and that these differences are grounded in different ideologies. Other scholars similarly make distinctions in types of citizenship (see for a review Johnson \& Morris, 2010). Westheimer and Kahne (2004) distinguish between a personally responsible, a participatory, and a social justice oriented citizen. Our distinction emerged from research on teachers' pedagogical goals, which showed that teachers can have different ideas about citizenship. Westheimer and Kahne did their research in a research project about in-service learning. They examined what students actually did in these projects and which goals were set for the projects. Therefore, their focus was more on how people can contribute to society and less on politics. A strong point of the Westheimer and Kahne typology, however, is the focus on social justice and on contributing to society. 
In our typology, the focus is on people's participation in the societal and political processes and power relations, and on the ideological orientation that people express in their conceptualisation of citizenship: is the focus on adaptation to norms, on developing and arguing one's individual views, or on acting as a critical and engaged participant in democratic processes. The typology is about the social and political way people participate in society and the ideology they use to substantiate their position. It is important to show in educational research and in teaching that different political and ideological articulations of citizenship are possible. Education should challenge youngsters to study different perspectives and to develop their own position in response.

\section{$4 \quad$ Teaching Common Values Democracy and Tolerance}

So far we have looked at the theory and practice of citizenship and citizenship education. However, educational policy can also express different articulations of citizenship. A country's education policy can address citizenship education in different ways and can emphasise different moral values. Between countries there can be commonalities and differences. This EDIC+ module focuses strongly on citizenship and citizenship education, in particular in Europe. The European Union has always stressed the relevance of the values of democracy and tolerance for Europe as a community as well as for its Member States.

At the request of the European Parliament we conducted a study on how, in all $28 \mathrm{EU}$ Member States, attention is devoted to the values of democracy and tolerance, both in policy and practice (Veugelers, De Groot, \& Stolk, 2017). This research focused on the policy of teaching the common values of democracy and tolerance in secondary schools, and how this policy is implemented in practice. Further, it covered how teachers, local communities and NGOs influence the teaching of common values. The education policy of all 28 European Union Member States was analysed by national academic experts, and indepth curriculum studies were performed in 12 Member States. The EDIC+ universities participated in the study and the study was a starting point for the curriculum development in EDIC+.

In the theoretical framework of the study, three components of democracy were distinguished: participation, democratic politics, and democratic society; as well as three components of tolerance: interpersonal relations, tolerance towards different social and cultural groups, and an inclusive society. Further, a distinction was made between a national and an international orientation. 
A review of existing relevant studies (e.g. CDP, 2005; ICCS, 2009) shows some evidence that students' value development is stimulated by a 'whole school approach' that incorporates the teaching of values in four ways:

- A specific value-oriented subject.

- Integration of values into related subjects.

- Cross-curricular activities that build links with the community.

- A democratic school culture, involving:

- more dialogical methodologies of teaching and learning,

- active participation of students in schools,

- inclusive education in bringing together different groups of students and teachers.

In this research, we investigated whether these elements are part of the education policies of the EU Member States, and whether schools and teachers are able to realise these elements in practice. We first present the main conclusions and then the recommendations.

\section{Conclusions}

\section{Policy}

Greater attention to the teaching of values, including democracy and tolerance, is evident in the education policies of all EU Member States. Although Teaching Common Values (TCV) is fairly important in half of the EU Member States, compared to other topics and subject areas the attention given to TCV is very meagre.

An analysis of the practice of TCV in 12 EU Member States shows that there are only a few Member States where the different components of teaching for democracy and tolerance receive systematic attention across schools. TCV is often not strongly implemented in education policy in terms of concrete curriculum instruments and supporting measures. This results in practices that do not always devote real attention to TCV. There is not only a gap between policy and practice, there is also a gap within policy: between general ideas and concrete measures. Moreover, the EU Member States differ in the extent to which they steer TCV policy.

In several EU Member States, there is a strong tendency to separate students into different groups based on different learning capacities. This reduces opportunities to learn about social and cultural differences. A second element that limits diversity among students is the prevalence of private or religious schools. 


\section{Curriculum}

In most EU Member States, there is a focus on political participation within the attention devoted to democracy. However, attention should also be given to two other elements of democracy: to democracy as a process of deliberation and consensus-building, and to the creation of a democratic society that is just and inclusive and values freedom of speech and equality. Education practices that relate to all these different components of democracy are scarce.

Tolerance is mostly addressed at the interpersonal level and to a larger extent at the level of cultural groups, but very little at the level of an inclusive society. While national orientation receives abundant attention in education policy, attention for the international dimension is not very strong, although it is growing. Teaching about national issues is mostly not very critical, however.

\section{Recommendations}

Based on the outcomes of the research we formulate recommendations at the different levels: EU, nation states, curriculum, schools.

\section{Policy}

Both the EU and each EU Member State has to take responsibility to support democracy and tolerance as common societal values and to support the sustainability of such a society. An intensive dialogue in society on what constitutes the common values and the role of education in promoting them is an expression of a lively democracy, and is a challenge for tolerance. EU Member States and the EU should support such dialogues. The EU can challenge its Member States to develop their own educational vision on Teaching Common Values like democracy and tolerance, stimulate the development of innovative practices, promote teacher and student exchange to help them experience different political and educational practices, and stimulate comparative research.

At the national level, education policy steering should target aims, guidelines for content and subjects, as well as activities. Further, education policy should challenge schools to use their relative autonomy to demonstrate their own vision and practice of $\mathrm{TCV}$. 


\section{Curriculum}

Greater attention should be given in education policy and practice to all three components of democracy. TCV also has to address all three elements of value development, namely knowledge, skills, and a democratic attitude. Besides tolerance, concepts with more positive attitudes such as appreciation, pluralism, and respectful engagement should be used. All three levels of tolerance (interpersonal relations, social and cultural groups, inclusive society) need more attention in education policy and practice.

Learning democracy and tolerance can be strengthened by cultivating social and cultural diversity in schools and classrooms. Education policy should stimulate diversity in education (among both students and teachers). Each country has to find the right balance in education between national and international orientation, so as to strengthen democracy and tolerance both nationally and internationally and to address both levels in a critical way.

Before the EDIC+ module starts, the participating students read the research report and analyse the case study of their own country, or the country of their university, and formulate concrete suggestions on how to improve the policy and practice of teaching democracy and tolerance.

In this module, students study different theories and concepts of citizenship and citizenship education. They learn to analyse national and local policies and practices of citizenship education. National (Dutch), comparative (focusing in particular on the participating countries), European, as well as global perspectives on citizenship and citizenship education will be covered. Intercultural aspects such as unity and diversity, psychological elements like engagement and emotions, and sociological variables such as social class, gender, religion and ethnicity will be included in the presented theories and analyses.

\subsection{Curriculum Framework}

In curriculum development it is important to formulate curriculum guidelines and a curriculum framework to steer the concrete programming of the module. In the theoretical part of the module, students learn about different 
theories of citizenship, citizenship education, moral education, intercultural education, and the possible links between these theories (see next section).

The comparative part of the module starts with in-depth analyses of the Dutch context of citizenship and citizenship education. After that, each student gives a critical presentation of citizenship and citizenship education in their own country (this presentation has to include small, personally-made video recordings). These presentations will be analysed jointly using national, European, and global perspectives. Interesting future-oriented theoretical, policy and practical directions will be delineated. The students analyse the Teaching Common Values report, paying particular attention to their own country, and how the recommendations in the report can improve teaching democracy and tolerance in educational policy, the curriculum, the schools, and the classroom in their country.

In this comparative part of the module, links are made with citizenship education outside Europe and the Western world: in Asia (Beijing, Singapore and Indonesia/Yogyakarta) and Latin America (Mexico and Argentina). The University of Humanistic Studies cooperates with these universities. Analyses and comparisons of these non-Western concepts and practices are made. In Skype meetings, students have dialogues with scholars outside Europe.

The third part of the module is more practice-oriented. Here students will apply theoretical concepts and comparative knowledge gained during the earlier part of the module. Students will study the citizenship curriculum practised at different levels of Dutch education (primary schools, secondary schools, and vocational schools). We try to include traditional schools, progressive schools, and multicultural schools. Groups of students will visit these schools, talk with teachers and pupils and will observe classes. The EDIC students will also give a short presentation to pupils about their own country and its citizens.

The second type of visit will be made to civil society organisations, e.g. Prodemos, Amnesty International, Anne Frank House, 'Fortress of Democracy', and the Humanist Ethical Association. Students will talk with staff members of these organisations about their educational activities. Experiences from both visits (schools and civil society) will be exchanged among students and analysed.

The module will be characterised by a research-oriented comparative approach (the place of citizenship education in schools and civil society in the different participating countries) and a linking of theory with practice. The final form of assessment will be a paper in which the students use the theory and the experiences gained from the module to design an educational policy and/or activity for a particular group of students in their own country. 
The innovative didactical aspect of this EDIC+ module is a stronger comparative approach that is more practice-oriented and is linked with civil society. It should enforce the knowledge, skills, and attitudes of (future) teachers, researchers and curriculum designers. Regarding the content, attention for the concepts of citizenship, democracy and intercultural society will be increased in educational studies.

Teachers in our past research projects often mentioned a lack of professionalism regarding citizenship education, particularly in diverse classrooms and with controversial issues. With this module we want to address these concerns and support future teachers in their pedagogical work.

The module will be open to all university students since citizenship education is a responsibility for every citizen, in particular every intellectual. Nevertheless, teachers, curriculum designers and educational researchers have a special role in this.

\subsection{Lectures and Visits}

In the module we focus on theory, policy and practice of citizenship education. We start the module with a presentation and discussion of the research on citizenship and citizenship education as outlined above. Other lectures are given by faculty members of the University of Humanistic Studies and by guest lecturers.

\subsubsection{Stories and Super Diversity}

Yvonne Leeman uses stories to prepare student-teachers for teaching in an inclusive society and for social justice: for living together in diversity and inclusivity. It is a means to identify differences and commonalities. Stories can provide for a safe encounter, help develop empathy, broaden one's view of the world, enable deep learning, stimulate the imagination, and offer multi-perspectivity. Stories confront a person with his/her process of identity development (confrontation with own culture, developing new orientations, reflexivity on own biography, narrative imagination). It is crucial to be touched by emotions, real encounters, experiences of being an outsider, and learning new cultural codes. Teachers can use stories in their classrooms and in their own professional development.

5.2.2 Cultivating Political Spaces in Schools

Isolde de Groot (2018) discusses how politics and political questions enter the classroom. How can political spaces be cultivating? For instance by having a mix of student voices, through influence in school on substantial components, 
meta-conversations, an appreciation of disruption and conflict, and through opportunities for 'democratic' student participation. As part of this approach: how can schools organise mock elections? By integrating more critical elements of democratic citizenship in mock-related education, and by contributing to a democratic school culture by increasing student involvement in the organisation of mock elections. Increasing room for such activities in the curriculum and the professional development of teachers in this respect are important conditions to enhancing the contribution of mock elections to democratic citizenship education.

\subsubsection{Strengths and Limitations of Democratic Experiences in Schools}

Isolde de Groot argues that "In many democratic societies, schools are expected to prepare their students for participation in democratic societies. (Self)assessment frameworks, designed by scholars and curriculum developers, support the development of school-initiated democratic experiences. Existing frameworks, however, are not designed to capture the interplay between the practices organised, related educational activities, and the types of aims pursued in education programmes. I present an eight-sectored framework that intends to capture the multiplicity of democratic education and participation in schools, and I discuss extreme cases and cases that sit at the intersection of the eight boxes. To explore the viability of the framework, I demonstrate how the framework can be used to identify strengths and limitations of how mock elections are organised in Dutch high schools".

\subsubsection{Democracy and Learning/Subjectification}

Gert Biesta (2011a, 2011b) challenges the notion of democracy. A community needs a wall: who is in, and who is out. Democracy is a political project. It is about what should have authority in our collective lives. Democracy is not 'flourishing' but limiting, not a common identity but political relationships; it is common world, not a common ground.

Democracy is not driven by individual desires but by what can collectively be considered desirable. It is not telling children what they should desire and what not, but making the question 'is what I desire desirable' into a living question. Educational work is about arousing the desire for a democratic way of life. Democracy is the condition of possibility for the existence of a plurality of values. Democracy is a fountain rather than a wall.

5.2.5 Philosophical Reflections on Tolerance

Political philosopher Filimon Peonidis of our EDIC+ partner Aristotle University Thessaloniki gave a lecture in which he presented a historical-philosophical 
analysis of the concept of tolerance. He showed that the concept refers to accepting otherness and that tolerance is in fact a quite recent phenomenon. It started, in the Western world, in the 16th century by accepting people who shook off traditional religious bonds. Tolerance is growing all over the world and is now considered to be part of human rights. However, human beings still have a long way to go to really live with tolerance and to change tolerance into appreciation.

\subsubsection{Citizenship Education in Mexico}

In a Skype session with Benilde Garcia-Cabrero of Autonoma University of Mexico, we discussed citizenship education in Mexico. Benilde clearly showed how social and political developments influence the kind of citizenship and citizenship education that is addressed in schools. After a period in which a conservative government emphasised national identity and adaptation and which created a loss of trust, the new more progressive government stimulates more active participation, rights and democratic engagement. Benilde argues for a better inclusion of emotions in citizenship education. Emotions have a great effect on changing moral values and attitudes. Benilde cautions against a too direct influence of politics on citizenship education: keep the good things and pay more attention to implementation.

\subsubsection{Citizenship and Moral Education in China}

In another Skype session, we discussed developments in moral and citizenship education with Chuanbao Tan and Lin Ke of the Center for Citizenship and Moral Education at Beijing Normal University. They explained that in China, moral education has traditionally been influenced strongly by Confucianism and that politically the focus was on responsibility and national identity. More recently there is attention for human rights and critical thinking as well. Modernisation in China requires citizens that respect human rights, cultural differences and can think critically in all domains of society: in economy, technology, politics, in social and cultural life, and in the natural environment. The challenge for China is to find the right balance between critical thinking, responsibility and social concern for the family, the nation and the global world. And also, between the national and the local, and the national and the global. Higher education and intellectuals have an important role in these societal developments.

\subsubsection{Student Participation in Curriculum Development}

Jeroen Bron is the coordinator of citizenship education at SLO, the Netherlands Institute for Curriculum Development, and the secretary of the taskforce for 
citizenship education of 'curriculum.nu'. In his $\mathrm{PhD}$ thesis, Bron (2018) focused on student participation in curriculum development. In his theoretical study he formulated five rationales for including a student voice in curriculum design: normative, developmental, political, educational, relevance. He developed a method to include all students in curriculum design and explored the method in six case studies. The studies showed that students can formulate topics to study and can make the curriculum more relevant, and that by exercising the method they can develop and demonstrate democratic citizenship qualities like communicating, cooperating and negotiating.

\subsubsection{Multicultural Secondary Education School}

We visited a multicultural school in Amsterdam and talked with the viceprincipal, a teacher and students. The school really wants to be multicultural but for them it is difficult to attract native Dutch students. The free school choice in the Netherlands hinders the school in becoming truly multicultural. Many students and parents in the Netherlands choose a school that is not diverse but similar to their own milieu.

The students were very engaged with the school and with their own future, but they were not happy with the fact that is very difficult for them to meet native Dutch youngsters, either in their school or outside school. They want to integrate into Dutch society, but Dutch society and Dutch people should give them more opportunities.

\subsubsection{Vocational Education}

Another school we attended was a school for secondary vocational education (ROC) in Utrecht. We spoke with the vice-principal, a teacher of citizenship education and students. Schools in Dutch education are required to pay attention to citizenship education, but it are the schools themselves (or even a specific department) that makes the actual programme. This department finds citizenship education very important, with a focus on moral reasoning, political participation and becoming engaged. Students have two hours a week of citizenship education, in addition to special projects at times. Citizenship education should develop critical thinking: 'to learn to think about how others view' and 'from outside to inside'. Students were very positive about these lessons, and in a lesson that we attended they learned about moral, social and political dilemmas.

\subsubsection{Fortress of Democracy}

As an example of an NGO that contributes to citizenship education we attended the 'Fortress of Democracy'. The fort was part of the 'waterlinie' (water defence 
system) built to protect Holland in case of war. During the cold war it served as an atomic bunker. Now it is a place where students can learn about democracy. Annually about 6ooo students visit the Fortress. There is a permanent exposition with nearly 100 questions and dilemmas relating to society and democracy. We were impressed by the creativity in the activities involved and the many different topics addressed. Examples of activities are questions about what contributes to democracy and what hinders democracy, knowledge about the Second World War, Dutch Jews in the Second World War, privacy, the 'Zwarte Piet' issue ('Black Peter'), facts and opinions, own moral values, power relations, etc. (www.fortvandedemocratie.nl).

The long-term aim is to develop a module of 7.5 ECTS. The regular format of a module at the University of Humanistic Studies is 10 weeks half time. In the future we hope to realise a joint international master $($ and $\mathrm{PhD})$ programme in the field of moral and citizenship education of at least 10 weeks. This programme will consist of the EDIC+ module, an additional module and writing a short essay. Together it should be 12 weeks (2O ECTS). Such a programme gives students the possibility to apply for an Erasmus exchange grant. As part of the EDIC+ Erasmus strategic partnership, the University of Humanistic Studies has already concluded Erasmus agreements with the other six participating universities. Now, in the developmental stage, we opt for what we call in EDIC+ the Intensive Programme format: a full-time week, with a preparation period and an essay afterwards. Three students of the University of Humanistic Students can combine this module with participation in the international Intensive Programme.

Programme Try-Out

(We present the text for the students.)

The central part of the module is one week full-time at the University of Humanistic Studies Utrecht: from January 29 until February 22018 (February 18-22, 2019). The preparation and the paper can be done in Utrecht or at the home university (guidance if necessary will then be given by Skype meetings). The minimum ECTs for the module is 5 , if your university requires another amount we can increase the student's activities. 


$\begin{array}{lll}\text { January } & \text { 2o hours } & \text { Preparation: reading and making presentation } \\ \text { January 29-February 2 } & \text { 40 hours } & \text { One week full-time in Utrecht } \\ \text { March-April } & \text { 8o hours } & \text { Paper (5 ECTS, can be max. 7.5 ECTS) }\end{array}$

8 Schedule EDIC+ Course University of Humanistic Studies Utrecht

8.1 Theory and Practice of Citizenship Education

Moderator Wiel Veugelers

Assistant Daniëlle Drenth

\section{Monday January 29}

9.30-10.30 Introduction

Of the participants. Of the programme. Practical information

10.30-12.30 Teaching Common Values Democracy and Tolerance

Presentation of research Wiel Veugelers. Discussion, see task 1

12.30-13.30 Dutch lunch together

13.30-16.oo Presentations of each participant: Moral and Citizenship Education in own country and/or in own research/study. See task 2

16.0o-17.0o Skype meeting with Benilde Garcia, University of Mexico Moral and Citizenship Education in Mexico and Latin America

17.30 Drinks in university cafeteria

Tuesday January $3^{\circ}$

9.30 Reflection

10.00-11.00 Different Concents of Citizenship and Citizenship Education Lecture of Wiel Veugelers

11.00-11.45 Practical preparation of visits Wednesday

12.30-14.30 Finding, Making and Using Stories for and about Living in Superdiversity

Lecture/workshop Yvonne Leeman

15.00-16.45 How to Slow Down Life without Stagnating Society: Resonance in an Accelerating World

Lecture by visiting German sociologist Hartmut Rosa 


\section{Wednesday January 31}

9.00 Travel to Amsterdam

10.00-12.30 Visit to School

A school for secondary education in a multicultural

surrounding

Talks with teachers and students

\section{Thursday February 1}

9.30-10.00 Reflection on programme Wednesday

10.00-12.00 Cultivating Political Spaces in Schools: The Case of Mock Elections Lecture/workshop Isolde de Groot

13.30-15.30 Guided tour in Utrecht, focus on Philosophical and Humanist topics

By Jules Brabers, Humanist Historical Centre

16.0o-18.oo Visit to Fortress of Democracy, Peace education

\section{Friday February 2}

9.30-10.00 Reflection on programme Thursday

10.00-12.30 Subjectification and Citizenship Education

Lecture by Gert Biesta

13.30-15.00 Discussing follow-up activities (finishing the module)

15.00-16.30 Evaluation

In the second year we made some small changes, so that we could try out some other activities.

9 Part of Schedule EDIC + Course University of Humanistic Studies Utrecht 2019

9.1 Theory and Practice of Citizenship Education

Wednesday February 20

$9 \cdot 30$

Philosophical Reflection on Tolerance

Prof. Filimon Peonidis, Aristotle University Thessaloniki

12.00-12.30 Lunch

12.30 Travel to school (bike or bus)

13.00-16.00 Visit to ROC Utrecht, a school for higher vocational education

Presentation and talks with teachers and students 


\section{Thursday February 21}

9.30-12.00 Visit to Fortress of Democracy

This is an NGO that organises activities for students on democracy and peace

13.30-15.30 Presentations of students about their own research

16.00-17.00 Moral and Citizenship Education in Mexico and Latin America Skype meeting with Prof. Benilde Garcia, University of Mexico

\section{Friday February 22}

9.30-10.30 Moral and Citizenship Education in China

Skype meeting with Prof. Tan and Dr Lin, Beijing Normal

University

11.00-13.00 Enhancing Students' Participation in Citizenship Education

Lecture by Dr Jeroen Bron SLO (National Institute of Curriculum Development)

Dr Bron coordinates the national curriculum development on citizenship education

13.00-13.30 Lunch

13.30-15.00 Finishing the module: conclusions and evaluation

10

Tasks for Students

\subsection{Task 1 Study Teaching Common Values Report}

Read the Teaching Common Values report (pp. 9-32 and pp. 181-202). And study three country case studies (1 North-Western Europe, 1 Eastern Europe, 1 South Europe): the case study reports of three countries and what is written about them in Chapters 4 and 6.

Questions:

1. What do you think are interesting and good examples (in policy and in practice)?

2. What needs improvement (in policy and practice)?

3. Which idea(s) will you use in your future educational practice?

Prepare some input for the discussion. The study can be downloaded at: http://bit.ly/2pm5Yh9

\subsection{Task 2 Personal Presentation}

Each participant gives a short presentation about moral and citizenship education in his/her own country and/or in the own research or other educational activities. Try to give a personal touch. Perhaps you can use some short video material. 
Each participant has maximum 15 minutes (if possible with some time for questions).

\subsection{Literature for Module}

Biesta, G. (2011). The ignorant citizen: Mouffe, Ranciere, and the subject of democratic education. Studies in Philosophy of Education, 30, 141-153.

Conde-Flores, S., Garcia-Cabrera, B., \& Alba-Meraz, A. (2017). Civic and ethical education in Mexico. In B. Garcia-Cabrero, A. Sandoval, E. Trevino, S. Diazgranados, \& M. Perez (Eds.), Civics and citizenship (pp. 41-66). Rotterdam, The Netherlands: Sense Publishers. De Groot, I. (2018). Political simulations. Democracy and Education, 16(2), 1-11.

Johnson, L., \& Morris, P. (2010). Towards a framework for critical citizenship education. The Curriculum Journal, 21(1), 77-96.

Print, M., \& Tan, C. (2015). Educating "good" citizens for a globalized world. In M. Print \& C. Tan (Eds.), Citizens in a global world for the twenty-first century (pp. 1-10). Rotterdam, The Netherlands: Sense Publishers.

Veugelers, W. (2011). The moral and the political in global citizenship education. Globalisation, Societies and Education, 9(3-4), 105-119.

Veugelers, W. (2017). Education for critical-democratic citizenship. Autonomy and social justice in a multicultural society. In N. Aloni \& L. Weintrob (Eds.), Beyond bystanders (pp. 47-59). Rotterdam, The Netherlands: Sense Publishers.

Veugelers, W., De Groot, I., \& Stolk, V. (2017) Research for cult committee - Teaching common values in Europe. Brussels: European Parliament, Policy Department for Structural and Cohesion Policies. Retrieved from http://bit.ly/2pm5Yh9

\section{Students' Experiences in the Module}

Students offered written feedback at the end of the EDIC + week, and they also formulated experiences and suggestions to improve the programme in their essay afterwards.

\subsection{Format and Organisation}

Students appreciated the intensity of the programme: one week full-time. They also appreciated the diversity in activities and the many teachers and other educational professionals with a lot of expertise that were involved in the programme. The visits to the multicultural school and the 'Fortress of Democracy' showed them critical practices.

The group was quite small, four Dutch students and four foreign students. However, the students saw this as an advantage. They could communicate a lot and had good contact with each other and the teachers. Some of them even argued in favour of keeping it this size. 


\subsection{Content}

The students found it very relevant to focus on theory, policy and practice of citizenship and the relationships between them. They realised that there are differences and that educators can make different choices in theory, strategies and practices. The school visit was to a secondary school with nearly only migrants. The experiences of these students, in the school system and in society, made them aware of the fact that the Netherlands is not yet an inclusive society and that school choice and early determination separate different social and cultural groups. The visit to the 'Fortress of Democracy' showed them how an NGO can challenge pupils to think about society, democracy and their role in it.

The lectures focused on different elements and perspectives on citizenship and citizenship education. Students appreciated this diversity and the opportunity to have many dialogues with the teachers and among themselves.

\subsection{Experiences in the Second Try-Out}

When finishing this chapter we had just completed our module for the second try-out. We had six Dutch students and six international students (Belgium, Italy, UK, Pakistan, USA, Zambia). Here are some of their experiences.

One of the most important things I became especially aware of during this week is the importance of national/local history and context when it comes to the local implementation of citizenship education. This became apparent as we discussed citizenship education in a variety of different countries through the participant presentations, readings and guest lectures. We can learn a great deal from sharing good practices across countries, but cannot simply 'copy and paste' a certain practice without taking into account the specific local context and history.

I really appreciated the variety of learning methods used during this module (participant presentations, discussion sessions, lectures, field visits, etc.), the diversity among the participants and lecturers as well as the combination of sessions focused on citizenship education in theory and citizenship education in practice. Most importantly, I have the feeling I am going home as a member of an empowering community of researchers and practitioners who share the common objective of making sense of and promoting citizenship education.

I found this week immensely enriching and enjoyed exploring complexities of moral philosophy, citizenship and the role of the citizen. I am leaving this week with a renewed commitment to a global critical democratic 
form of citizenship. I was particularly interested to learn from our colleagues from out of Europe (Zambia, Pakistan, China and Mexico) and was reminded of things we take for granted about our curriculums in Central/Western European countries.

It was emphasised that good citizenship education is not the transmission of a static set of values nor an adherence to a strict set of criteria. It was communicated that citizenship education, when undertaken well, is a reflexive, empathetic and transformative discipline that has a lot to offer young people across the world. It made me realise that, if we want more emphasis on a European/global citizenship education, we may have to fight for it!

I greatly enjoyed the presentations of my classmates. I found that I had a lot to learn from my classmates and was very appreciative of the fantastic mixture of practices, disciplines, nationalities and inclinations of the other students. We worked well as a group and my classmates stimulated a lot of critical thinking, which I am very grateful for.

I learned how the Netherlands took humanism seriously and the pride the residents had in being humanists. I learned how openly the topic of diversity and religion was discussed in Netherlands.

I learned that there are many different views on citizenship and moral education and it can be done right and wrong in many ways, and everything in between.

I found the lectures very interesting as they offered me new standpoints and new perspectives on how to approach history and how to design more inclusive lessons, where pupils have the possibility to express their voice and be more active during decision making.

I learned how different European countries approach citizenship education when I read the Teaching Common Values case studies and we discussed it. We also learned how Mexico approaches citizenship education and how their policies are affected with the change in governments. I found the conversation with Mexico very interesting for the reason that she was able to show that training works when you are in the field with the teachers and not when you deliver superficial workshops. We learned how China was now starting to discuss human rights. We also learned that they want to progress in their ideas towards citizenship education. 
The teachers were great at creating an open, relaxed, and inclusive environment.

Overall, I can say I undoubtedly learned a substantial amount about the manifestation of civic and moral education around the world, the best practices for this form of education, and the role of the state in civic and moral education. The module also helped me refine my own conception of moral and civic education and how I feel that I would put it into practice in the classroom.

The visits were appreciated a lot:

Fortress of Democracy provided me with many interesting ideas to stimulate discussion and practice with children I work with - I am interested in the ways that disabled children are often not expected to think critically despite often having the capability to do so. I would like to introduce some of the concepts explored at the Fortress in a gentle way.

My favourite activity was visiting the мво school, and it was so interesting to see Dutch students participating in citizenship education and hearing their own (extremely well-spoken) experiences and opinions. It really made me want to go back into the classroom myself. I also loved visiting the Fortress of Democracy. It was interesting to experience firsthand how citizen education is attempted in schools, through NGos.

Visiting the Fortress after the school was good. The school triggered to think about how to apply citizenship education for this target group. The Fortress provided some answers to it.

And the last quote:

The best thing was: meeting everyone and sharing ideas.

\section{References}

Andreotti, V. (2011). The political economy of global citizenship. Globalisation, Societies and Education, 9(3-4), 307-310.

Apple, M., \& Beane, J. (Eds.). (2005). Democratic schools. Portsmouth, NH: Heinemann. 
Banks, J. (Ed.). (2004). Diversity and citizenship education: Global perspectives. San Francisco, CA: Jossey-Bass.

Banks, J. (Ed.). (2017). Citizenship education and global migration. Washington, DC: AERA.

Barber, B. (1984). Strong democracy. Berkeley, CA: University of California Press.

Biesta, G. (2011a). Learning democracy in school and society. Rotterdam, The Netherlands: Sense Publishers.

Biesta, G. (2011b). The ignorant citizen: Mouffe, Ranciere, and the subject of democratic education. Studies in Philosophy of Education, 30, 141-153.

Bourdieu, P. (1984). Distinction. London: Routledge.

Bron, J. (2019). Student voice in curriculum development. Utrecht: University of Humanistic Studies.

Conde-Flores, S., Garcia-Cabrera, B., \& Alba-Meraz, A. (2017). Civic and ethical education in Mexico. In B. Garcia-Cabrero, A. Sandoval, E. Trevino, S. Diazgranados, \& M. Perez (Eds.), Civics and citizenship (pp. 41-66). Rotterdam, The Netherlands: Sense Publishers.

Crick, B. (1999). The presuppositions of citizenship education. Journal of Philosophy of Education, 33(3), 337-352.

De Groot, I. (2013). Adolescents' democratic engagement. Utrecht: University of Humanistic Studies.

De Groot, I. (2018). Political simulations. Democracy and Education, 16(2), 1-11.

Durkheim, E. (1971[1923]). Moral education. New York, NY: Free Press.

Freire, P. (1985). The politics of education: Culture, power and liberation. South Hadley, MA: Bergin \& Garvey.

Gaudelli, W. (2016). Global citizenship education: Everyday transcendence. New York, NY: Routledge.

Giddens, A. (1990). The consequences of modernity. Cambridge: Polity.

Giroux, H. (1989). Schooling for democracy. London: Routledge.

Goodlad, J. (1979). Curriculum inquiry. New York, NY: McGraw-Hill.

Goren, H., \& Yemini, M. (2016). Global citizenship education in context: Teacher perceptions at an international and a local Israeli school. Compare, 46(5), 832-853.

Green, A., \& Janmaat, J. (2011). Regimes of social cohesion. London: Palgrave.

Gutman, A. (1987). Democratic education. Princeton, NJ: Princeton University Press.

Haste, H. (2004). Constructing the citizen. Political Psychology, 25(3), 413-440.

Hess, D. (2009). Controversy in the classroom. New York, NY: Routledge.

International Civic and Citizenship Education Study. (2010). ICCS 2009 International Report. Amsterdam: IEA.

International Civic and Citizenship Education Study. (2017). ICCS 2010 International Report. Amsterdam: IEA. 
Isin, E., \& Turner, B. (Eds.). (2002). Handbook of citizenship studies. London: Sage Publications.

Johnson, L., \& Morris, P. (2010). Towards a framework for critical citizenship education. Curriculum Journal, 21(1), 77-96.

Kennedy, K., Lee, W., \& Grossman, D. (Eds.). (2010). Citizenship pedagogies in Asia and the Pacific. Dordrecht: Springer.

Kerr, D. (1999). Citizenship education in the curriculum: An international review. The School Field, $10(3-4), 5-31$.

Leenders, H., Veugelers, W., \& De Kat, E. (2008a). Teachers' views on citizenship in secondary education in the Netherlands. Cambridge Journal of Education, 38(2), 155-170.

Leenders, H., Veugelers, W., \& De Kat, E. (20o8b). Moral education and citizenship education at pre-university schools. In F. Oser \& W. Veugelers (Eds.), Getting involved: Global citizenship development and sources of moral values (pp. 57-74). Rotterdam, The Netherlands: Sense Publishers.

Leenders, H., Veugelers, W., \& De Kat, E. (2012). Moral development and citizenship education in vocational schools. Education Research International. doi:10.1155/2012/901513

Lickona, T. (1991). Educating for character. New York, NY: Random House.

Marshall, T. H. (1964). Class, citizenship and social development. Chicago, IL: University of Chicago Press.

McLaren, P. (1989). Life in schools. New York, NY: Longman.

McLaughlin, T. (1992). Citizenship, diversity and education: A philosophical perspective. Journal of Moral Education, 21(3), 235-250.

Mouffe, C. (2005). On the political. London: Routledge.

Mouffe, C. (2018). For a left populism. London: Verso.

Noddings, N. (2002). Educating moral people. New York, NY: Teachers College Press.

Nussbaum, M. (1997). Cultivating humanity. Cambridge, MA: Harvard University Press. OECD. (2016). Netherlands 2016: Foundations for the future. Paris: OECD.

Oser, F., \& Veugelers, W. (Eds.). (2008). Getting involved. Global citizenship development and sources of moral values. Rotterdam, The Netherlands: Sense Publishers.

Osler, A., \& Starkey, H. (2010). Teachers and human rights education. London: IOE Press.

Oxley, L., \& Morris, P. (2013). Global citizenship: A typology for distinguishing its multiple conceptions. British Journal of Educational Studies, 3, 301-325.

Parker, W. (2003). Teaching democracy. New York, NY: Teachers College Press.

Power, F., Higgins, A., \& Kohlberg, L. (1989). Lawrence Kohlberg's approach to moral education. New York, NY: Columbia University Press.

Print, M., \& Tan, C. (2015). Educating "good" citizens for a globalized world. In M. Print \& C. Tan (Eds.), Citizens in a global world for the twenty-first century (pp. 1-10). Rotterdam, The Netherlands: Sense Publishers.

Reilly, J., \& Niens, U. (2014). Global citizenship education as education for peacebuilding in a divided society. Compare, 44(1), 53-76. 
Sim, J. (2011). Social studies and citizenship for participation in Singapore: How one state seeks to influence its citizens. Oxford Review of Education, 37(6), 743-761.

Teodore, A., \& Guilherme, M. (Eds.). (2014). European and Latin American Higher Education between mirrors. Rotterdam, The Netherlands: Sense Publishers.

Torney-Purta, J. (2002). Pattens in the civic knowledge, engagement, and attitudes of European Adolescents. The IEA Civic Education Study. European Journal of Education, 37(2), 129-141.

Torres, C. A. (2017). Theoretical and empirical foundations of critical global citizenship education. New York, NY: Routledge.

Touraine, A. (1997). What is democracy. Boulder, CO: Westview Press.

Veugelers, W. (2007). Creating critical-democratic citizenship education: Empowering humanity and democracy in Dutch education. Compare, 37(1), 105-119.

Veugelers, W. (2011a). Theory and practice of citizenship education: The case of policy, science and education in the Netherlands. Revista de Educacion, 209-224.

Veugelers, W. (2011b). The moral and the political in global citizenship education: Appreciating differences in education. Globalisation, Societies and Education, $9(3-4), 473-485$.

Veugelers, W. (2017a). The moral in Paulo Freire's educational work. Journal of Moral Education, 46, 412-421.

Veugelers, W. (2017b). Education for critical-democratic citizenship. Autonomy and social justice in a multicultural society. In N. Aloni \& L. Weintrob (Eds.), Beyond bystanders (pp. 47-59). Rotterdam, The Netherlands: Sense Publishers.

Veugelers, W. (in press). Different views on global citizenship. In D. Schugurensky \& C. Wolhuter (Eds.). Global citizenship education and teacher education. London: Routledge.

Veugelers, W., De Groot, I., Llomovatte, S., \& Naidorf, J. (2017). Higher education, educational policy and citizenship development. Education and Society, 35(1), 27-42.

Veugelers, W., De Groot, I., \& Stolk, V. (2017). Research for cult committee - Teaching common values in Europe. Brussels: European Parliament, Policy Department for Structural and Cohesion Policy. Retrieved from http://bit.ly/2pm5Yh9

Veugelers, W., \& de Kat, E. (2003). Moral and democratic education in secondary schools. In F. Oser \& W. Veugelers (Eds.), Teaching in moral and democratic education (pp. 193-213). Bern: Peter Lang.

Westheimer, J., \& Kahne, J. (2004). What kind of citizen? The politics of educating for democracy. American Educational Research Journal, 41(2), 237-269. 